\title{
EXCLUSION OF INCOMPETENT EVIDENCE FROM FEDERAL GRAND JURY PROCEEDINGS
}

The trial determination of conviction or acquittal follows other stages of the criminal process at which tentative judgments are made about the gtilt or in nocence of the defendant. These stages-arrest, preliminary hearing, indictment-may be viewed as a series of pre-trial screens designed to pass persons apparently guilty of a crime along the path toward ultimate adjudication while eliminating from the process those who seem innocent. ${ }^{1}$ From the moment the initial decision to arrest or indict is made until the termination of the case, the subject remains at all times liable to sanctions: deprivations of life, liberty, dignity, and property resulting from state acts purposely directed against him. The commonly accepted reasons in the criminal law for applying sanctionsretribution, restraint, rehabilitation, and general deterrence-all presuppose guilt." Because of the presumption of innocence," "guilt" within the criminal process can be defined only in terms of conviction and thus can be applied only after the fact of conviction; "innocence," on the other hand, unless an individual has been acquitted, represents a state that may at any time turn into guilt. ${ }^{4}$ Thus, when sanctions are inflicted at preconviction stages they are necessarily borne by innocent people. The justification for the infliction of sanctions against persons presumptively innocent is the need for an efficacious and fair procedure leading to conviction. But the presumption of innocence requires that the imposition of preconviction sanctions be kept at a minimum consistent with allowing the process to run its course. ${ }^{5}$

If preconviction sanctions ${ }^{6}$ are to be kept within a process leading to conviction, the evidence considered at pretrial stages should, to the extent feasible,

1. See generally Orfiedd, Criminal Procedure from Arrest to Appent 3-193 (1947); A. Goldstein, The State and the Accused: Balance of Advantage in Criminal Procedure, 69 YALE L.J. 1149, 1163-72 (1960).

2. In the case of an innocent man, a condition essential to each justification of sanctions is left unsatisfied: retribution presumes a motivating wrong; rehabilitation assumes a manifested criminal defect; general deterrence presupposes a causal relationship between misconduct and sanction; and, within a society that values individual freedom, individual restraint must be preceded by conduct suggestive of future undesirable acts which underlic restraints placed on an individual. See generally, Donnelix, Goldstern \& Scuwakrz, Crtminal Law 498-518 (1962).

3. For a discussion of the operative effect of the presumption of innocence within the broad context of the criminal process, see A. Goldstein, The State and the Actused: Ballance of Advantage in Criminal Procedure, 69 Y ALE L.J. 1149 (1960).

4. Acquittal at trial because of the prohibition against double jeopardy is a prospectively conclusive statement of a person's innocence in relation to certain events. Prospectiveness can also be injected into "innocence" by the running of the statute of limitations or the grant of statutory immunity, both forms of "acquittal" without trial.

5. J. Goldstein, Police Discretion Not to Invoke the Criminal Process: Low Visibility Decisions int the Administration of Justice, 69 Y ALE L.J. 543, 549-50 (1960).

6. Indictments, for example, act as sanctions by depriving those accused of self-respect and by setting or keeping in motion a process that may produce a deprivation of liberty, 
be limited to that evidence which would be admissible at trial. At present, there are no general provisions in federal law for implementing at the grand jury hearing those qualitative evidentiary standards applicable at trial. This permits decisions requiring an individual to stand trial to be based upon various forms of incompetent evidence. The effectivê exclusion of incompetent evidence from the grand jury, however, would require engrafting judicial safeguards upon proceedings which have traditionally been subject to a minimum of external checks. Although not approving the use of incompetent evidence, commentators have justified nonintervention in all pretrial proceedings on the grounds that rigorous adherence to the panoply of safeguards at trial will afford sufficient protection to the accused and that judicial control and safeguards at pretrial stages would hamper other necessary functions of the process. ${ }^{7}$ For instance, it is believed that "judicializing" the grand jury proceedings would impair the usefulness of the grand jury as an investigating agency. Such a view not only assumes too generally that safeguards at particular stages in the pretrial process will impair other functions but also overlooks the fact that the sanctions resulting from mere involvement in the process may be severe. Because variations between evidentiary standards used at trial and at grand jury proceedings may distort the relationship between indictment and the likelihood of conviction at trial, an examination of the feasibility of imposing trial-type evidentiary standards on federal grand juries seems warranted. ${ }^{8}$

through detention and restriction, and of property, through lost earnings, defense expenses, and bail. In addition, regard for grand jury findings has an impact on socicty that may result in a further deprivation of the accused's dignity by alienating the respect of the community. In order to minimize pretrial sanctions both efficiently and effectively, many substantial changes in the structure of the pretrial process would be required. Full implementation of such policy might be deemed to necessitate the abrogation of the secrecy and ex parte character of the grand jury proceeding or the development of a full adversary procedure at the preliminary hearing. A discussion of this, however, is beyond the scope of this Note.

7. A. Goldstein, The State and the Accused: Balance of Adzantage in Criminal Procedure, 69 Y ALE L.J. 1149 (1960).

8. No one can be held for criminal trial in a federal court for an "infamous" crime unless he either has been indicted by a grand jury or has waived indictment.

The fifth amendment provides that "no person shall be held to answer for a capital, or otherwise infamous crime, unless on a presentment or indictment of a Grand Jury. ..." An infamous crime is one that may be punished by hard labor or imprisonment in a penitentiary. Ex parte Wilson, 114 U.S. 417 (1885); United States v. MForeland, 238 U.S. 433 (1922). Anyone sentenced to a term of imprisonment of more than one year may be confined in a penitentiary. 18 U.S.C. $\$ 4083$ (1958).

The Federal Rules of Criminal Procedure recognize that the initiation of prosecutions by presentment is obsolete. Note of Advisory Committee to Rule 7(a), 6 N.Y.U. Scrroor of LaW INSTITUTE Proceedings 15 (1946).

Prosecutors are permitted to proceed by information when a defendent waives in open court his right to have a prosecution initiated through indictment. FED. R. Cruss. P. 7(b). In 1961, 19,145 federal criminal proceedings were commenced through indictment, and in 9,167 cases, indictment was waived. During the previous year, 18,677 prosecutions stemmed from indictment, while 9,335 cases started with an information after a waiver of indictment. 1961 ANn. Rep. DiR. of The U. S. Courts 272.

Grand jury indictments are not required by the federal Constitution for state prosecutions. Hurtado v. California, 110 U.S. 516, 538 (1884). State use of grand juries varies 
Ideally, the grand jury should look to guilt and innocence for its guide in determining whom to indict, but since no distinction between guilt and innocence is made until trial, the grand jury cannot directly apply these concepts as a meaningful guide. It can, however, use these concepts indirectly by con* sidering the possibility of an individual's conviction on the basis of a given body of evidence. While the presumption of innocence prohibits the ascription of "guilt" except upon conviction, its broadening of "innocence" to incltude all states of nonconviction suggests the need for a prospective view of a subject's innocence--prognostic innocence. A man is prognostically innocent when the body of evidence relating to him cannot lead to conviction at trial. In screening out unfounded accusations, the grand jury should not indict anyone prognostically innocent in relation to the evidence it has heard; the foundation for the accusation of such a person cannot lead to a destruction of his state of innocence, and therefore the sanctions induced cannot be justified as part of a process leading to conviction. The test derived from this is susceptibility to conviction: has sufficient evidence been presented at the ex parte grand jury hearing so that, if nothing more were heard at trial, a petit jury could conclude that the prosecution had successfully borne the burden of proof ? ${ }^{0}$ The answer to this question is not absolute as to guilt, but is predictive of how a petit jury could react in the absence of an explanation by the defendant.

Functioning within the framework of its predictive purpose, the grand jury tests the prosecutor's case for conviction. The grand jury's performance of its adjudicatory role may, however, be distorted as a result of the prosecutor's close relationship with the panel. The judge, although available to answer legal questions, rarely has further contact with the grand jury after giving a general charge. ${ }^{10}$ The prosecuting attorney draws up charges, outlines the

widely. Compare, e.g., N.Y. Const. art. 1, §6 with CAL. Penal Code $\$ 737$ (1954). The analysis in this Note applies equally well to the grand juries in those states where indictments are the usual means of proceeding against an individual.

9. Compare this test with those of Chief Justice Taney in Charge to Grand Jury, 30 Fed. Cas. 998, 999 (No. 18,257) (C.C.D. Md. 1836) ("You will, therefore, . . . present no one, unless, in your deliberate judgment, the evidence before you is sufficient, in the absence of any other proof, to justify the conviction of the party accused.") ; Justice Field in Charge to Grand Jury, 30 Fed. Cas. 992, 994 (No. 18,255) (C.C.D. Cal. 1872) ("To justify the finding of an indictment you must be convinced, so far as the evidence before you goes, that the accused is guilty -in other words, you ought not to find an indictment unless, in your judgment, the evidence before you, unexplained and uncontradicted, would warrant a conviction by a petit jury.") ; and Judge Kaufman in The Grand Jury-Its Role and Its Power, 17 F.R.D. 331, 335 (1955) ("Your prime function is to decide whether or not sufficient evidence has been produced to indicate that a crime probably has been committed by the person accused. Or, stated another way: if upon the credible evidence which you have heard, absent an explanation by the defendant, you would be willing to convict, you should indict."). But see Note, 62 HARv. L. Rev. 111 n.5 and accompanying text (1948): "The purpose of the grand jury investigation is to protect the accused against unfounded or malicious prosecutions by insuring that no criminal proceedings will be undertaken without a prior, disinterested determination of probable guilt."

10. See Kaufman, The Grand Jury-Its Role and Its Powcr, 17 F.R.D. 331, 336 (1955) ; Dession, From Indictment to Information-Implications of the Shift, 42 Y ALE L.J. 163,177 (1932). 
government's case, calls and examines witnesses, presents evidence, sets forth the law, and requests findings. 11 Through the discharge of these responsibilities, the prosecutor acquires a position of superintendence over grand jury proceedings. The grand jury's dependence on the prosecutor is heightened by its lack of independent sources of evidence.12 The secrecy of the hearings and the absence of everyone except grand jury members, stenographers, prosecutorial personnel, interpreters when required, and the witness under examination ${ }^{13}$ strengthen the prosecutor's position by substantially precluding external checks on his conduct. In addition to the formal relationship, a prosecutor and grand jury may work together for a long period of time, creating a rapport and sense of common purpose which can vest additional power in the prosecutor. ${ }^{14}$ With the power to influence the grand jury, the prosecutor bears special responsibilities to conduct his case before it fairly. He must recognize the tension created by his dual role of adversary and administrative officer; while using evidence for its full probative value he should not distort or color it to prejudice the position of the accused. The effective functioning of the grand jury as a pretrial screen designed to minimize sanctions upon persons who are not susceptible to conviction is endangered by the possibility that the prosecutor will assume a total adversary role prematurely. ${ }^{10}$

The prosecutor may not use certain kinds of evidence at trial. Since this incompetent evidence cannot be used to convict and is therefore not relevant to a determination about susceptibility to conviction, admissibility before a grand jury acting within its predictive purpose should likewise be limited to competent evidence. If incompetent evidence is admitted, a grand jury, assessing the probative value of the evidence it hears, will not dismiss the incompetent material from consideration and may not even discount it, for competency bears no necessary relationship to credibility. ${ }^{10}$ In the absence of a restraint on

11. Orfield, The Federal Grand Jury, 22 F.R.D. 343, 382-84, 425 (1959), and the cases cited therein; Lewin, The Conduct of Grand Jury Proceedings in Antitrust Cases, 7 LAw \& CONTEMP. PROB. 112, 126-29 (1940).

12. Dession \& Cohen, The Inqutisitorial Functions of Grand Juries, 41 YALE L.J. 687, 696-99 (1932).

13. FED. R. CRIMr. P. 6(d).

14. Federal Rule of Criminal Procedure 6(g) provides that grand juries may serve for as long as eighteen months. Justice Bernard Botein of the Appellate Division of the New York Supreme Court, a former prosecutor, suggests the existence of just such an intimate relationship between prosecutor and grand jury. See Botern, The Prosecutor ch. 14 (1956).

15. See id. generally.

16. While some forms of incompetent evidence, such as hearsay testimony, are generally excluded because their reliability as proof of an event is questionable, McConsmcr, EvrDENCE § 224, at 457-59 (1954), other varieties are held inadmissible in order to further public policies not directly related to the trial. For example, the exclusion of illegally seized evidence is considered a means to prevent undesirable police tactics. Weeks v. United States, 232 U.S. 383 (1914). Likewise, the rules which establish privileged relationships evince a choice of encouraging openness in the specified relationships over providing completeness in the testimony at trial. McCoranck, EvIDENCE § 72, at 152 (1954). See generally, 8 WIGssone, Evidence \$§ 2175-2396 (McNaughton ed. 1961). 
the use of incompetent evidence, the predictive judgment of the grand jury can be distorted. Presently, there are no effective checks to prevent the prosecutor from presenting to the grand jury any evidence he wants to introduce. ${ }^{17}$ Thus the prosecutor can obtain indictments in cases where he would be unable to satisfy the burden of proof. Whether the prosecutor's action is intentional, thits qualifying as harassment-the imposition under color of law of sanctions prior to conviction as a means of ultimate punishment ${ }^{18}$-or is unintentional, sanctions inflicted upon persons other than those susceptible to conviction are not consistent with giving full weight to the demands of the presumption of innocence. ${ }^{19}$

Where the basis of evidentiary incompetence is a violation of the search and seizure provision of the fourth amendment, such evidence is presently suppressible at any time before trial under Rule 41 (e) of the Federal Rules of Criminal Procedure. ${ }^{20}$ No parallel remedy for other forms of incompetency is prescribed. But if susceptibility to conviction is to be a meaningful criterion for grand jury determinations, an extension of the remedy afforded by Rule 41 (e) is necessary. The courts of appeals of two circuits, out of five which have considered the problem, have stated that the Rule 41 (e) remedy extends to evidence obtained in violation of the fifth amendment's self-incrimination provision, ${ }^{21}$ and one Circuit judge has suggested in a concurrence that all

17. Statements urging that only competent evidence be presented to the grand jury have not attained the stature of a legal rule in federal courts because the policy thus forwarded has not been enforced. See e.g., United States v. Reed, 27 Fed. Cas. 727, 735 (No. 16,134) (C.C.N.D. N.Y. 1852) ("Evidence before a grand jury must be competent legal evidence, such as is legitimate and proper before a petit jury."); Thompson \& MERruna, ConduCt of JuRIEs 692 (1882) ("Although the hearing of testimony is largely removed from the superintendence of the court, the prosecuting officer should never attempt to introduce testimony, which, upon a jury trial, would be regarded as incompetent.").

18. See J. Goldstein, Police Discretion Not to Invoke the Criminal Process: Low Visibility Decisions in the Administration of Justice, 69 Y YLE L.J. 543, 580-86 (1960). At least some prosecutors are neither unaware of the uses of harassment nor unwilling to cmploy it. Id. at 583-84.

19. See note 5 supra and accompanying text.

20. A person aggrieved by an unlawful search and seizure may move the district court for the district in which the property was seized for the return of the property and to suppress for the use as evidence anything so obtained on the ground that (1) the property was illegally seized without warrant, or (2) the warrant is insufficient on its face, or (3) the property seized is not that described in the warrant, or (4) there was not probable cause for believing the existence of the grounds on which the warrant was issued, or (5) the warrant was illegally executed. The judge shall receive evidence on any issue of fact necessary to the decision of the motion. If the motion is granted the property shall be restored unless otherwise subject to lawful detention and it shall not be admissible in evidence at any hearing or trial. The motion to suppress evidence may also be made in the district where the trial is to be had. The motion shall be made before trial or hearing unless opportunity therefor did not exist or the defendant was not aware of the grounds for the motion, but the court in its discretion may entertain the motion at the trial or hearing.

FEd. R. CRIAr. P. 41(e).

21. Holding for suppression are the Fourth and Second Circuits in Austin v. United States, 297 F.2d 356 (4th Cir. 1961) and In re Fried, 161 F.2d 453 (2d Cir. 1947), respec- 
illegally obtained evidence should be suppressed.22 The foundation upon which Rule 41 (e) is based-the power of courts to develop and enforce rules of evidence and to supervise the conduct of attorneys who appear before themappears to support pretrial suppression of all types of incompetent evidence.23 The societal aim of discouraging police employment of offensive tactics by prohibiting the utilization of the products of such practices is generally applicable. ${ }^{24}$ The distinction which isolates for special treatment fourth amendment violations has no basis in reason $;^{25}$ instead, it seems rooted in the fortuities of historical growth.28 At the time Rule 41 (e) was drafted, pretrial suppression had been effected only in cases of fourth amendment violations. Although Rule 41 (e) is merely a restatement of the law existing when it was drafted ${ }^{27}$ and carries no implication that the applicability of its remedy is restricted, courts have been hesitant to extend this pretrial remedy. ${ }^{28}$

tively. The principal cases opposing this view are Biggs v. United States, 246 F.2d 40 (6th Cir. 1957) ; Centracchio v. Garrity, 198 F.2d 382 (1st Cir. 1952) ; and Eastus v. Bradshaw, 94 F.2d 788 (5th Cir. 1938).

22. See the opinion of Judge Jerome Frank in In re Fried, 161 F.2d 453, 460 (2d Cir. 1947).

23. Compare Weeks v. United States, 232 U.S. 383, 398 (1914), and Wise v. Henlel, 220 U.S. 556, 558 (1911), with Eastus v. Bradshaw, 94 F.2d 788, 789 (5th Cir. 1938).

24. To the extent that the grand jury provides a forum in which illegally obtained evidence can be utilized, the exclusionary policy articulated in Weeks v. United States, 232 U.S. 383 (1914), will be undermined.

25. The property right argument that Rule 41 (c) provides for the return of private property wrongfully taken by the government, used to justify the distinction, is invalid. In re Fried, 161 F.2d 453, 458 (2d Cir. 1947). But see Eastus v. Bradshaw, 94 F.2d 788, 789 (5th Cir. 1938). The rule explicity provides for the suppression as evidence of nonreturnable, unlawfully seized contraband; furthermore, testimony about what was seen during an illegal search has been held inadmissible. McGinnis v. United States, 227 F.2d 598 (1st Cir. 1955).

26. Pretrial suppression entered the law as a method of excluding the products of illegal searches and seizures. Weeks v. United States, 232 U.S. 383 (1914), distinguishing Adams v. New York, 192 U.S. 585 (1904). Such evidence, unlike involuntary confessions, was not incompetent because of its questionable probative value, which at that time was the only reason for which the source of evidence was relevant to its admissibility. Adams v. United States, 192 U.S. 585, 594 (1904). The requirement that objections to evidence obtained in illegal searches and seizures be made before trial was later eased, and the fruits of fourth amendment violations, as well as other forms of illegally obtained evidence, were subject to challenge at trial. See Gouled v. United States, 255 U.S. 298 (1921). The potentialitics of pretrial suppression were consequently not fully exploited.

27. Note of Advisory Committee to FEd. R. Crrar. P. 41 (e), 6 N.Y.U. Scrool of LAw Instrtute Proceedings 70 (1946).

28. Such orders do not infringe on grand jury freedom. To be protected is the grand jury's freedom in determining how it will pursue and dispose of subjects of inquiry. As with all parts of the criminal process, the latitude of the grand jury's permissible action is circumscribed by a framework of procedural regulations. For example, a grand jury cannot compel someone to give self-incriminatory testimony. See Brown v. Walker, 161 U.S. 591 (1896). Once it is decided that incompetent evidence takes the grand jury outside its permissible area of activity, it cannot be said that enjoining the prosecutor from presenting that evidence infringes on the historic freedom of the grand jury. 
Attempts to limit the basis of grand jury decisions to evidence admissible at trial are complicated by the fact that the issues and direction of the case have not yet been fully developed. Because the precise nature of the charges is not defined prior to indictment, questions about the admissibility of evidence at trial which turn on the content of the accusation cannot be answered before the grand jury acts; ${ }^{29}$ questions concerning evidence whose admissibility depends on a particular situation developing at trial are likewise unanswerable at this pretrial stage. ${ }^{30}$ Principles of economy dictate that suppression motions should be granted only when the evidence could not be used at trial under any circtinstances. Otherwise, the program for effecting exclusion could develop into a burdensome series of motions testing the admissibility of evidence within changing and specific pretrial contexts. Thus, exclusion of incompetent evidence from grand jury proceedings should be limited to evidence that in relation to an individual is determinably excludable under all circumstances. Under this "determinably excludable" test, coerced confessions, products of illegal searches, seizures, and wiretaps, and evidence breaching a privileged relin tionship, could be suppressed; some hearsay evidence or evidence of questionable relevance could not.

Most of the problems in implementing exclusionary rules are attributable to our extreme reluctance to impose external controls upon grand jury proceedings. ${ }^{31}$ It is thought that minimal interference with the grand jury hearings benefits both the prosecutor's investigation of cases and the objectivity of the grand jurors' indictment decisions. Checks on the proceedings sufficient to provide a full opportunity for individuals to challenge evidence would entril opening the hearings, thereby sacrificing the secrecy believed essential to grand jury operations. ${ }^{32}$ If exclusion depends on an individual's knowledge that the

29. Relevance has been considered an essential element for the admissibility of cvidence since evidence not relevant could logically have no probative effect on the issucs at trial. Thayer, Prelminary Treatise on Evidence 264-66 (1898). A definition of the accusation logically precedes any decision about whether a given piece of evidence is relevant to a determination about the truthfulness of the charges against an individual. Since the product of grand jury action is a statement of the charges that an accused individual will have to answer at trial, determinations about the relevance of evidence must await indictment.

30. For example, hearsay evidence can be used to impeach the testimony of a witncss by demonstrating inconsistency among his statements. 3 WIGMORE, EvideNCE $\$ 1018$, at 687 (3d ed. 1940). Since the statement at trial of the assertion to be impeached must precede the invocation of this exception to the hearsay rule, there can be no pretrial determination about whether such hearsay evidence will be admitted at trial.

31. See, e.g., Costello v. United States, 350 U.S. 359 (1956).

32. Secrecy encourages free expression from witnesses by confining knowledge of the testimony and thereby reducing fear of reprisal; protects suspects from the extra-legal sanctions that could attach to someone suspected of crime but not indicted if the grand jury's suspicions were publicized; insulates the grand jury's investigative and adjudicative processes from outside pressures by keeping the public ignorant of the cases under consideration; and minimizes the likelihood of successful perjury or subornation, which could be accomplished through later witnesses conforming their testimony to that given earlier, or to escape to avoid arrest under an imminent indictment. See Orfield, The Federal Grand Jury, 22 F.R.D. 343, 403 (1959). 
prosecutor has incompetent evidence which can be used against him, only limited success in effectuating the grand jury's predictive purpose can be expected. It may be feasible to introduce a pre-indictment check directly into the proceedings in the form of a master who would attend the hearings with the power to raise a claim of privilege on behalf of its owner ${ }^{33}$ and to challenge other forms of incompetent evidence on the basis of an extension of Rule 41(e). This check will be effective chiefly where, because of the relationship of the parties involved or the character of the evidence, the existence of the incompetency is apparent on the face of the evidence. Whether the extent of abuse warrants the expenditure of a master's time and effort is uncertain, although there may be other benefits to be derived from his presence. For example, it would minimize the informal influence which a prosecutor can exert over the grand jurors. ${ }^{34}$

Without affecting secrecy, exclusion of incompetent evidence from grand jury proceedings would further be effectuated if objection to the use of such evidence could be raised by the defendant after the indictment has been returned. ${ }^{35}$ A defendant, once notified of the accusation, might well become cognizant of the use of incompetent evidence in the grand jury hearings. Upon the defendant's motion, a judge would examine the grand jury minutes to discover whether the alleged introduction of incompetent evidence occurred. If such evidence was used, a court would either quash the indictment, necessitating another grand jury hearing, or determine whether the competent evidence heard by the grand jury was sufficient to support an indictment. While this practice could considerably mitigate the problems of enforcing an exclusionary policy, it might virtually invite challenges to all indictments. ${ }^{30}$ In any case, the Supreme Court's pronouncements on postindictment challenges indicate it is unlikely that this method of implementation will be adopted. ${ }^{37}$

Opposition to pretrial motions excluding incompetent evidence from grand jury proceedings centers upon the administrative difficulties such motions would entail. ${ }^{38}$ On examination, however, these difficulties may not be serious enough to outweigh the value of insuring a valid predictive judgment. In many

33. 8 WIGMORE, EVIDENCE $\S 2196$, at 112 (MicNaughton ed. 1961); MCCorurrer, EvrDENCE $§ 73$, at 152 (1954).

34. See notes 11-18 supra and accompanying text.

35. See, e.g., People v. Glen, 173 N.Y. 395, 400, 66 N.E. 112, 114 (1903).

36. See State v. Chance, 29 N.M. 34, 39, 221 Pac. 183, 185 (1923).

37. If indictments were to be held open to challenge on the ground that there was inadequate or incompetent evidence before the grand jury, the resulting delay would be great indeed. The result of such a rule would be that before trial on the merits a defendent could always insist on a kind of preliminary trial to determine the competency and adequacy of the evidence before the grand jury. This is not required by the Fifth Amendment. An indictment returned by a legally constituted and unbiased grand jury, like an information drawn by the prosecutor, if valid on its face, is enough to call for trial of the charge on the merits. The Fifth Amendment requires nothing more.

Costello v. United States, 350 U.S. 359, 363 (1956).

38. See Note, 60 HARv. L. Rev. 1145, 1151-52 (1947). 
cases, allowance of suppression motions will lengthen the criminal process. On the other hand, a pretrial determination against the competency of evidence has an ameliorative effect on the trial stage by eliminating the disruptive and distracting in camera hearing on admissibility and by reducing the length of the trial; a pretrial ruling upholding competency has no effect on the trial stage. Any pretrial determination concerning evidentiary competence necessitates an extra hearing; but the Federal Rules recognize other instances where extra hearings are justified, ${ }^{30}$ and the reasons for this hearing seem sufficiently strong to warrant the fragmentization it will produce. Unsuccessful pretrial motions require additional effort from the judiciary, the prosecutor, and witnesses. For the prosecutor and witnesses, this increment takes the form of a duplication of their trial functions and therefore involves little more than an expenditure of time. ${ }^{40} \mathrm{~A}$ hearing judge must become conversant with the facts bearing on admissibility, and when a different judge presides at trial, the inconvenience is somewhat greater. When the motion to suppress succeeds, the hearing has resulted in little extra effort, and the net effect is simply a change in the tining of the competency determination. Although frivolous claims may be raised, they can be disposed of with ease. Where no indictment or arrest would have been sought or effected on the basis of the challenged evidence, the loss of time and effort would be more striking. An off-setting saving may result where the incompetence of the evidence on which the prosecutor based his case is pointed out, prompting the abandonment of the action before it reaches advanced stages in the criminal process. Finally, the principal objection against pretrial suppression motions-the opportunity for dilatory appeals-has been emasculated by a recent Supreme Court holding that rulings on such motions are interlocutory and hence not immediately appealable. ${ }^{41}$

Recognizing that the grand jury's "adjudicating" and "investigating" functions merely denote poles on a continuum and that they are often operative simultaneously, it is still appropriate to prescribe separate rules acknowledging the differences so that the investigating power will not be materially affected by a rule designed to improve the performance of the adjudicating function. When the grand jury is operating primarily as a investigative body, it may hear any evidence. If it hears evidence which has been suppressed, it may not proceed against the individual who secured the suppression or on whose behalf it was secured, but rather the case of any individual so immunized

39. Among the motions that can be made during the pretrial period and necessitate extra hearings are the 7 (d) motion to strike surplusage from an indictment or information; the $7(f)$ motion for a bill of particulars; the $12(\mathrm{~b})(1)$ motion to raise before triat any defense that can be disposed of without a trial of the general issue; the 12(b) (2) motion based on defects in the institution of the prosecution; and the 21 (a) motion to transfer the proceedings because of prejudice in the district. FED. R. CRIM. P. 7(d), 7(f), 12(b) (1), $12(\mathrm{~b})(2), 21(\mathrm{a})$.

40. The witnesses may not even be required to attend the hearing since pretrial suppression motions are usually decided on affidavits. DiBella v. United States, 369 U.S. 121, $129 \mathrm{n.9}$ (1962).

41. Id. at 131 . 
should be referred to another grand jury for adjudication. A grand jury performing its adjudicative function may hear all evidence competent against any suspect. If it hears evidence that has been suppressed, it may not indict the individual who obtained the suppression order. His case is referred to a different adjudicative grand jury which will not hear the suppressed evidence. Since evidence incompetent against one person may be admissible against another, a prosecutor in a case involving multiple defendants must choose between using suppressed evidence, thereby immunizing the suppressor from an indictment by that grand jury, and sacrificing the evidence in order to continue the proceedings against all. This problem is particularly acute in big cases, such as antitrust prosecutions or cases arising from broad investigations, where a grand jury may accumulate evidence for months.

The direct effect of a pretrial suppression remedy is necessarily limited. In the first place, not all forms of incompetency can be challenged, and secondly, the basis of incompetency may be such that neither the interested parties nor a master at the hearing would be cognizant of those facts which would induce a challenge. To the extent that challenges are made, however, decisions about what evidence should be used before grand juries become visible $t 2$ and hence reviewable. By giving some substance to a rule limiting the grand jury to competent evidence, preindictment suppression should exert an important exhortative force on prosecutors, thus discouraging the use of incompetent evidence. Because it is believed that some effective provision for enforcement must be included if policy is to be implemented, this scheme for pre-indictment suppression seems preferable to a simple statutory declaration, which some states have, ${ }^{43}$ that only competent evidence should be used at grand jury hearings. ${ }^{44}$

42. For a discussion of visibility in a different context, see generally J. Goldstein, Police Discretion Not to Invoke the Criminal Process: Low Visibility Decisions in the Administration of Justice, 69 YALE L.J. 543 (1960).

43. See, e.g., N.M. Stat. ANN. § 41-5-22 (1953), and State v. Chance, 29 N.A. 34, 39, 221 Pac. 183, 184-85 (1923).

44. It may be argued that the extension of procedural safeguards to grand jury hearings will pervert the grand jury's role by leading the petit jury to attach undue respect to the findings of the earlier panel. Nothing indicates, however, that this innovation in grand jury operations would elicit substantially greater respect from the petit jury. Since it is unlikely that the petit jury now assumes that the grand jury hears incompetent evidence, the clange should have little effect on the relationship. At any rate, the greater danger lies in a belief that grand jury accusations might represent a more accurate appraisal of absolute as opposed to systemic guilt, a belief that could follow from the inapplicability at the grand jury stage of what might seem to the layman to be "technical" rules of evidence which operate to hide "truth." To the extent that the uniform application of rules of competency at all stages in the criminal process destroys such a belief, the danger that the petit jury will believe in the "veracity" of grand jury findings is minimized, and community confidence restored to its rightful place, the final determination by the petit jury. 